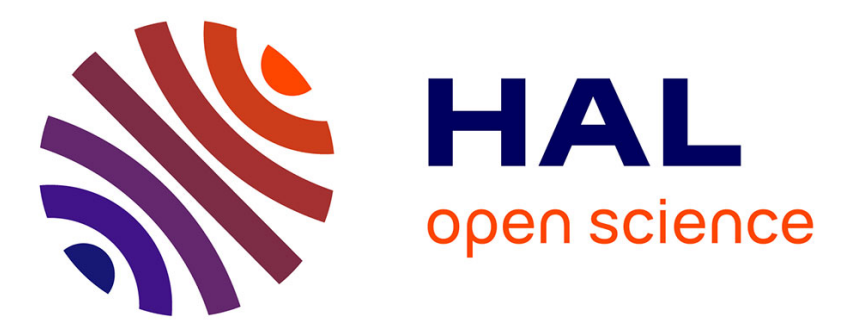

\title{
Slip distribution of the 2003 Boumerdes-Zemmouri earthquake, Algeria, from teleseismic, GPS, and coastal uplift data
}

B. Delouis, M. Vallée, M. Meghraoui, E. Calais, S. Maouche, K. Lammali, A. Mahsas, P. Briole, F. Benhamouda, K. Yelles

\section{- To cite this version:}

B. Delouis, M. Vallée, M. Meghraoui, E. Calais, S. Maouche, et al.. Slip distribution of the 2003 Boumerdes-Zemmouri earthquake, Algeria, from teleseismic, GPS, and coastal uplift data. Geophysical Research Letters, 2004, 31, pp.L18607. 10.1029/2004GL020687 . hal-00407308

\section{HAL Id: hal-00407308 https://hal.science/hal-00407308}

Submitted on 1 Feb 2021

HAL is a multi-disciplinary open access archive for the deposit and dissemination of scientific research documents, whether they are published or not. The documents may come from teaching and research institutions in France or abroad, or from public or private research centers.
L'archive ouverte pluridisciplinaire HAL, est destinée au dépôt et à la diffusion de documents scientifiques de niveau recherche, publiés ou non, émanant des établissements d'enseignement et de recherche français ou étrangers, des laboratoires publics ou privés. 


\title{
Slip distribution of the 2003 Boumerdes-Zemmouri earthquake, Algeria, from teleseismic, GPS, and coastal uplift data
}

\author{
B. Delouis, ${ }^{1}$ M. Vallée, ${ }^{2}$ M. Meghraoui,${ }^{3}$ E. Calais, ${ }^{4}$ S. Maouche,${ }^{5}$ K. Lammali, ${ }^{5}$ \\ A. Mahsas, ${ }^{5}$ P. Briole, ${ }^{6}$ F. Benhamouda, ${ }^{7}$ and K. Yelles ${ }^{5}$ \\ Received 5 June 2004; revised 23 July 2004; accepted 18 August 2004; published 23 September 2004.
}

[1] Using a joint inversion of seismological waveforms and ground displacement observations, we estimate several parameters of the fault geometry and rupture process of the $\mathrm{Mw}=6.9$ May 21, 2003 Boumerdes-Zemmouri earthquake. The relocated epicenter is considered as a known parameter. Total rupture length, rupture duration, and maximum slip are $55 \mathrm{~km}$ (from $3.4^{\circ} \mathrm{E}$ to $4.0^{\circ} \mathrm{E}$ ), $12 \mathrm{~s}$, and $3 \mathrm{~m}$. The modeled south dipping reverse fault, oriented ENE-WSW outcrops a few $\mathrm{km}$ offshore which is consistent with the absence of observed surface rupture inland. Two shallow and relatively localized slip zones are found, on both sides of the hypocenter. To the SW, between Boumerdes and Zemmouri, slip is concentrated between 11 and $2 \mathrm{~km}$ depth. To the NE, between Zemmouri and Dellys, slip is concentrated between $6 \mathrm{~km}$ depth and the sea floor. Various resolution tests indicate that our model is well constrained by the available data, and help understanding which data constrains each parameter of the model. INDEX TERMS: 1242 Geodesy and Gravity: Seismic deformations (7205); 7209 Seismology: Earthquake dynamics and mechanics; 7215 Seismology: Earthquake parameters. Citation: Delouis, B., M. Vallée, M. Meghraoui, E. Calais, S. Maouche, K. Lammali, A. Mahsas, P. Briole, F. Benhamouda, and K. Yelles (2004), Slip distribution of the 2003 Boumerdes-Zemmouri earthquake, Algeria, from teleseismic, GPS, and coastal uplift data, Geophys. Res. Lett., 31, L18607, doi:10.1029/2004GL020687.

\section{Introduction}

[2] The Mw = 6.9 May 21, 2003 Boumerdes-Zemmouri earthquake occurred beneath the northern coast of Algeria, about 50 kilometers east of Algiers [Ayadi et al., 2003]. Maximum intensity (EMS98 X) was observed in cities and villages located along the coast, among which Boumerdes and Zemmouri. Centroid moment tensor solutions from global or regional seismological networks indicate a reverse faulting mechanism with a fault plane oriented NE-SW or ENE-WSW (e.g., HCMT, USGS, ETHZ, INGV centroids).

\footnotetext{
${ }^{1}$ UMR 6526, CNRS, Géosciences Azur, Nice, France.

${ }^{2}$ Osservatorio Vesuviano, Istituto Nazionale di Geofisica e Vulcanologia, Naples, Italy.

${ }^{3}$ UMR 7516, CNRS, Institut de Physique du Globe, Strasbourg, France.

${ }^{4}$ Department of Earth and Atmospheric Sciences, Purdue University, West Lafayette, Indiana, USA.

${ }^{5}$ Centre de Recherche en Astronomie, Astrophysique et Geophysique (CRAAG), Algiers, Algeria.

${ }^{6}$ UMR 7580, CNRS, Institut de Physique du Globe, Paris, France. Algeria.

${ }^{7}$ Institut National de Cartographie et de Télédétection (INCT), Algiers,
}

Copyright 2004 by the American Geophysical Union. 0094-8276/04/2004GL020687
No surface ruptures directly related to the earthquake was found in the field, preventing discrimination between the two candidate fault planes. However, the vicinity of the upper part of the fault to the shoreline was proved by the large coastal uplift observed between Boumerdes and Dellys (Figure 1). Modeling the horizontal coseismic displacement measured at nine GPS points [Yelles et al., 2004] showed that the correct fault plane is the south dipping one. This means that any surface rupture would be off-shore and this is consistent with the absence of such observation in-land. This solution is also in good agreement with the fact that the reverse faults bordering the Mitidja Basin near Boumerdes [Meghraoui, 1991] as well as those identified offshore along the Algerian margin [Déverchère et al., 2003] are south dipping faults. Using the master event technique, the epicenter, originally found offshore (CRAAG location [Yelles-Chaouche et al., 2003]), has been relocated on the coastline at $36.83^{\circ} \mathrm{N}$ and $3.65^{\circ} \mathrm{E}$ [Bounif et al., 2004, Figure 1].

[3] A preliminary model of slip distribution based on teleseismic P waves Y. Yagi (see http://iisee.kenken.go.jp/ staff/yagi/eq/algeria20030521/algeria2003521.html, 2003) has proposed that the rupture occurred at shallow depth, with a larger extension in the SW direction. A more refined description taking into account body $\mathrm{P}$ and $\mathrm{SH}$ waves as well as surface waves [Vallée et al., 2003] has precised these first findings. In particular, the analysis of surface waves, following the technique described by Vallée [2004], has clearly shown the bilaterality of the rupture, with a global extension of about $60 \mathrm{~km}$. Teleseismic data alone, however, have a limited resolution, and an accurate determination of the space and time distribution of slip requires additional constraints brought by measurements of near source static ground displacements. For that purpose, we invert jointly teleseismic body waves, GPS, and coastal uplift data.

\section{Coseismic Data}

[4] Broadband seismograms from the mainshock recorded at teleseismic distances were obtained from the IRIS and ORFEUS data centers. In the inversions, we use velocity waveforms windowed around the $\mathrm{P}$ and $\mathrm{SH}$ wave trains, well distributed azimuthally. Data processing is the same as that of Delouis et al. [2002]. P waveforms exhibit a complex shape which indicates that the rupture involved more than a single slip zone, as will be confirmed by the slip inversion.

[5] Coseismic horizontal displacements were obtained by resurveying a 9-site GPS network and details of GPS processing can be found in work by Yelles et al. [2004]. Stations at Boumerdes and more to the west display 


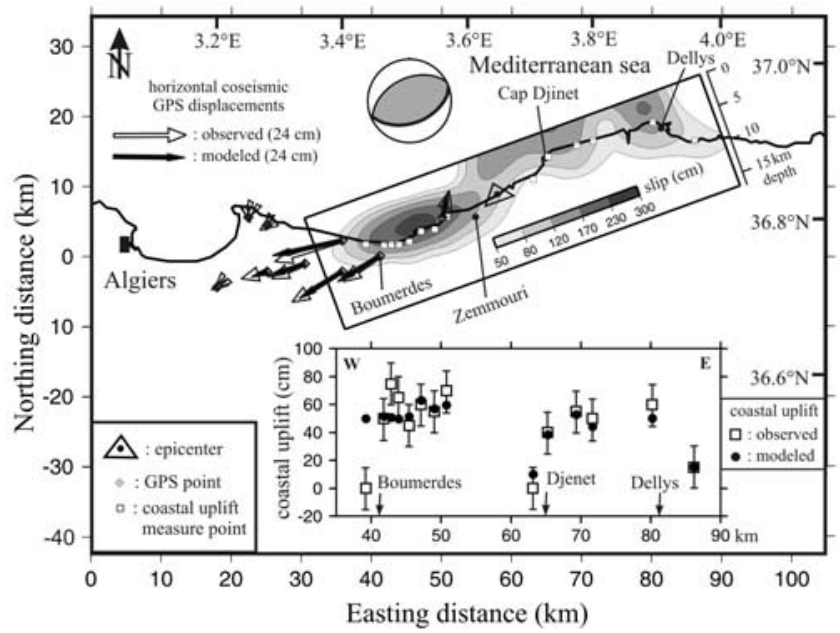

Figure 1. Geographical setting and results. The surface projection of the slip map resulting from the joint inversion of teleseismic, GPS, and coastal uplift data is draw under the coastline within a rectangle showing the overall dimensions of the fault model. Also shown is the GPS and Coastal uplift data fitting. The average focal mechanism determined in this study is represented on top, with the south dipping plane underlined. Symbols explained within the figure.

horizontal vectors oriented WSW, i.e., almost parallel to the reverse fault strike, with maximum amplitude of $24 \mathrm{~cm}$ (Figure 1). Yelles et al. [2004] show that such a pattern can be modeled with a rupture plane whose top edge is located at a few km depth.

[6] Coastal uplift could be measured at several points along the rocky shores using the height of the white fringe formed by dead intertidal algae, with an uncertainty estimated to $\pm 0.15 \mathrm{~m}$ in relation to the tide level (M. Meghraoui et al., Coastal uplift and thrust faulting associated with the $\mathrm{Mw}=6.8$ Zemmouri (Algeria) earthquake of 21 May, 2003, submitted to Geophysical Research Letters, 2004, hereinafter referred to as Meghraoui et al., submitted manuscript, 2004). Coastal uplift exhibits two distinct areas of vertical displacement, one between Boumerdes and Zemmouri, with up to $0.75 \mathrm{~m}$ of uplift, and a second one between Cap Djinet and Dellys (Figure 1). Uplift decreases to zero between Zemmouri and Cap Djinet, as well as west of Boumerdes and east of Dellys with a possible transition to subsidence. Such a "camel-like" envelope of vertical displacement suggests two separate patches of coseismic slip, as found also by Meghraoui et al. (submitted manuscript, 2004).

\section{Fault Model and Inversion Procedure}

[7] We first investigated the focal mechanism of the mainshock by modeling the $\mathrm{P}$ and $\mathrm{SH}$ broadband waveforms at teleseismic distances. We carried out a grid search on the strike, dip, rake, and source depth parameters, representing the event by a propagating line source. As a solution for the south dipping plane we obtained (strike, dip, rake, depth $)=\left(70^{\circ}, 40^{\circ}, 95^{\circ}, 6 \mathrm{~km}\right)$. Synthetic seismograms were generated using the ray theory [Nabelek, 1984]. The crust in the source region and under the stations is represented by a simple half-space.
[8] To determine the space and time distribution of coseismic slip, we use a finite fault model following the approach of Delouis et al. [2002]. The model consists of a single rupture plane $60 \mathrm{~km}$ long and $24 \mathrm{~km}$ wide extending from the surface to a depth of $17 \mathrm{~km}$, subdivided into 40 subfaults measuring $6 \mathrm{~km}$ along both strike and dip. In our model, rupture is constrained to initiate at the center of one of the subfaults, whose geographical position coincides with the mainshock epicenter relocated by Bounif et al. [2004]. The depth of the model hypocenter is $6.5 \mathrm{~km}$. The azimuth and dip of the fault model were fine-tuned to $70^{\circ}$ and $45^{\circ}$ respectively by performing a series of joint inversions of the three data sets with different fault geometries. In the inversion procedure, which is based on a simulated annealing algorithm, the rake angle is allowed to vary between $65^{\circ}$ and $125^{\circ}$ (dominant reverse component). Subfault source time functions are represented by three isosceles triangular functions of variable amplitude with $3 \mathrm{sec}$ duration, mutually overlapping. Subfault slip onset times are allowed to vary within the interval defined by two bounding rupture velocities, 1.6 and $3.4 \mathrm{~km} / \mathrm{s}$. Static displacements (for GPS and coastal uplift) are computed using the dislocation formulation of Savage [1980].

[9] The cost function to be minimized in the simulated annealing procedure is defined as the weighted sum of the normalized RMS (L2 norm) misfit errors of the different datasets, with an additional function aiming at minimizing the total seismic moment. In the joint inversion, the different datasets were equally weighted. The choice of the data weighting and the selection of the misfit function in relation with the data statistics [e.g., Amoruso et al., 2002] may have important effects on the results. However, we verified that the slip distributions resulting from the joint inversion differ only in minor detail when the combination of weights is changed or when a L1 (instead of a L2) norm misfit function is used (see auxiliary material ${ }^{1}$ ).

\section{Results and Resolution Tests}

[10] The slip distribution resulting from the joint inversion is shown in map view (surface projection) in Figure 1, together with the modeling of GPS and coastal uplift data. The May 21st, 2003 earthquake involved two slip zones, one located SW of the hypocenter, the other one to the NE, for a total rupture length of $55 \mathrm{~km}$. Each slip zone represents about $50 \%$ of the total seismic moment amounting to $2.9 \times$ $10^{19} \mathrm{Nm}\left(\mathrm{M}_{\mathrm{w}}=6.9\right)$. The maximum slip amplitude, ca $3 \mathrm{~m}$, occurred within the SW slip zone, which did not reach the surface but was confined to the depth range 11 to $2 \mathrm{~km}$. The NE slip zone was shallower and extended mainly from $6 \mathrm{~km}$ depth to the surface. Rupture propagated bilaterally from the hypocenter, but with asymmetrical properties. Significant slip $(>0.5 \mathrm{~m})$ propagated at greater depth and slowly (1.6 to $1.9 \mathrm{~km} / \mathrm{s}$ ) towards the $\mathrm{SW}$, at shallower depth and faster (2.0 to $2.4 \mathrm{~km} / \mathrm{s}$ ) towards the NE (Figure 2). Strong deviations of the slip vector from pure reverse faulting were not required by the data (black arrows in Figure 2). Most of the seismic moment (85\%) was released within 12 seconds

\footnotetext{
${ }^{1}$ Auxiliary material is available at $\mathrm{ftp}: / / \mathrm{ftp}$.agu.org/apend/gl/ 2004 GL020687.
} 


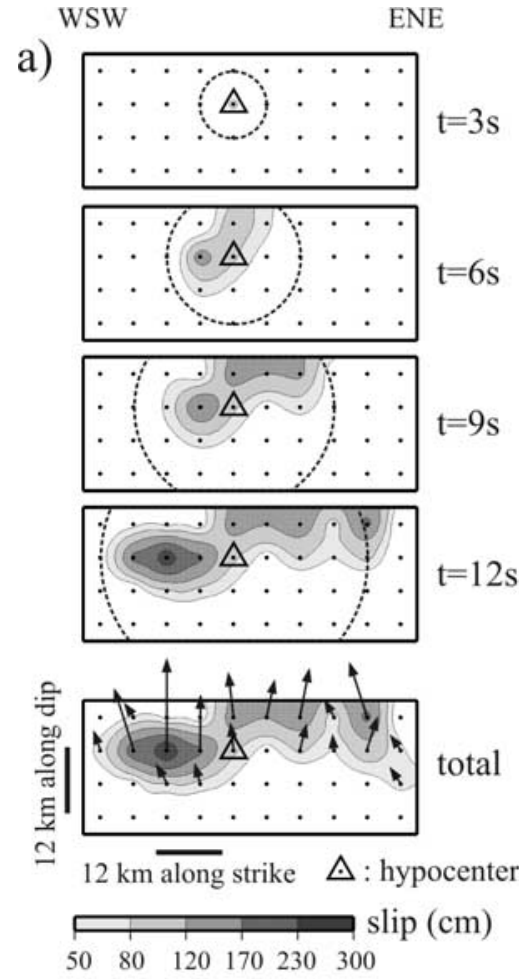

b)

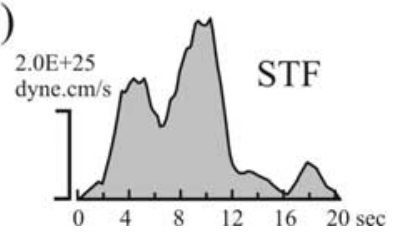

Figure 2. (a) Space-time evolution of the rupture represented by the cumulative slip at different times after rupture initiation, resulting from the joint inversion. The dashed circle shows a theoretical rupture front propagating at $2 \mathrm{~km} / \mathrm{s}$ for reference. "total" is the final slip map, with black arrows representing slip vectors (hanging wall slip motion). (b) Moment rate Source Time Function (STF) for the whole rupture.

(see STF in Figure 2). P and SH waveform fitting is shown in Figure 3.

[11] We carried out resolution tests in order to evaluate how the spatial distribution of slip was constrained (Figure 4). In these tests, the geometry, model parameters, and their bounding values, as well as the data configuration and inversion procedure were the same as for the real data inversions. The synthetic slip model (Figure 4, top) contains three patches of slip. This model was used to generate synthetic data (teleseismic, GPS, and coastal uplift) which were inverted separately and jointly. Some noise was added to the synthetic data before inversion, which varied between \pm 10 and $\pm 1 \mathrm{~cm}$ for coastal uplift and GPS data, respectively, and $\pm 10 \%$ of the amplitude for the teleseismic data. Moreover, synthetic seismograms were randomly time shifted by up to $\pm 1 \mathrm{~s}$. Three patches were retrieved by the inversion of coastal uplift data, but with a noticeable distortion. Due to their partial coverage of the rupture zone, GPS data retrieve only the westernmost patch, illustrating the trade-off that may exist between the data and the resulting source model.

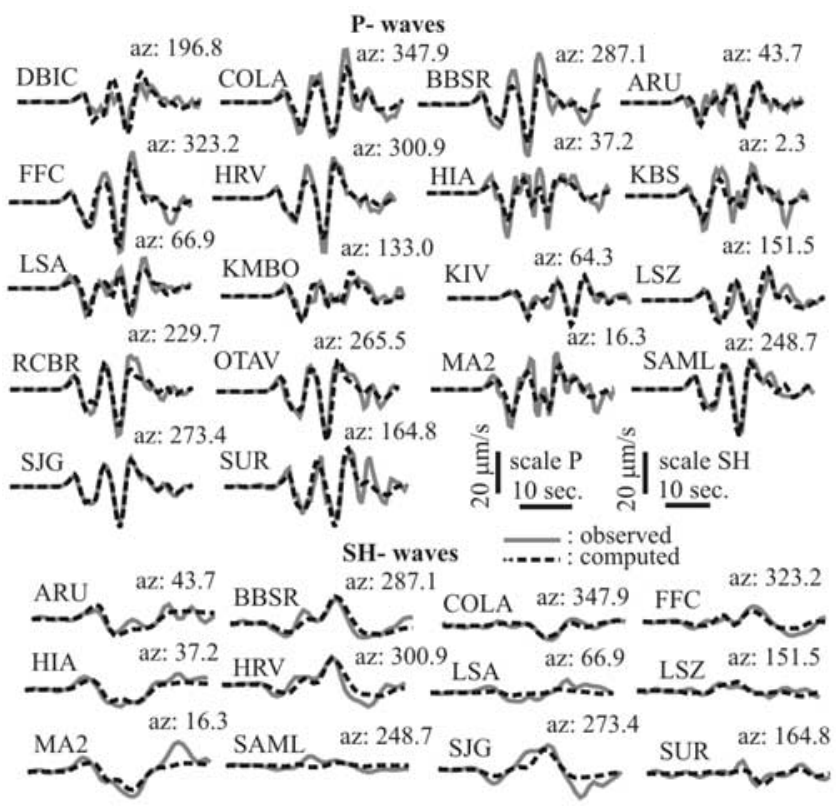

Figure 3. Waveform fit for the $\mathrm{P}$ and $\mathrm{SH}$ waves in velocity, from the joint inversion. Signals were bandpassed from $0.01 \mathrm{~Hz}$ to $0.8 \mathrm{~Hz}$ (P waves) or $0.4 \mathrm{~Hz}$ (SH waves).

As observed in other cases [e.g., Delouis et al., 2002], teleseismic data, when inverted alone, tend to spread out slip over a wide area of the fault model. However, when inverted jointly with near source ground displacements,

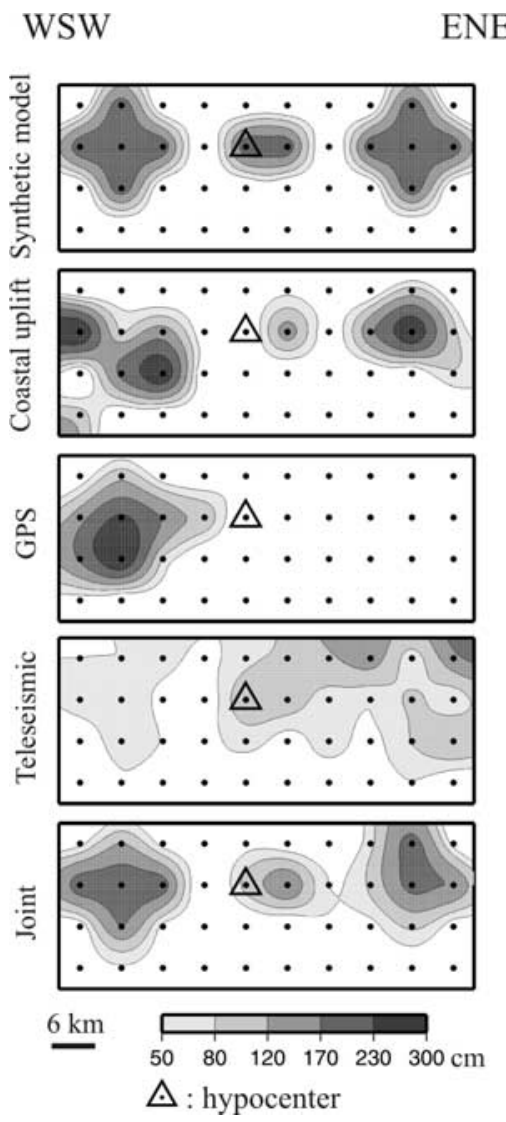

Figure 4. Slip maps from the resolution tests, for separate datasets and joint inversions. 
teleseismic data contribute positively to the determination of the slip distribution. Globally, the main characteristics of the entire synthetic model are well retrieved, with an increased resolution in the west due to the specific contribution of the GPS data. These tests, as well as those showing the small dependency of the results with the data weighting (auxiliary material), indicate that the effect of the trade-off between individual datasets and the resulting slip distribution is strongly reduced in the joint inversion.

\section{Discussion and Conclusion}

[12] Provided the a priori fixed parameters, in particular fault strike, dip, and position, are correctly defined, resolution tests show that the slip distribution resulting from the joint inversion is well determined. Fault strike and dip were adjusted using the three complementary datasets available to us, and position was constrained by the relocated epicenter as well as by the near source ground displacement data. Our fault model is in agreement with the aftershock distribution [Bounif et al., 2004] and with the orientation of reverse faults identified further offshore by Déverchère et al. [2003].

[13] The SW slip zone is particularly well constrained as it is located near the GPS network. The fact that the NE slip zone is found very close to the coastline may suggest that the inversion could be biased by the linear distribution of coastal uplift data. However, slip immediately below the coast and at shallow depth is required to explain the high gradient of vertical displacement near Cap Djinet and Dellys (Figure 1). Deeper slip would produce vertical uplift with a smoother and longer wavelength shape. Moreover, synthetic tests have shown that this part of the model is well enough resolved, with a positive contribution of teleseismic data in the joint inversion. The shallow character of slip is a strong requisite of the teleseismic data.

[14] Some features of the coastal uplift pattern in the Boumerdes-Zemmouri area could not be reproduced by the model, such as the very short wavelength variation of uplift around the $0.75 \mathrm{~m}$ peak value (Figure 1). This indicates that we may have underestimated the uncertainty on the coastal uplift data or that secondary earthquake-related motions occurred locally near the surface. The very abrupt return to zero from Boumerdes ( $0.5 \mathrm{~m}$ of uplift) to the next measuring point situated only $2.5 \mathrm{~km}$ more to the west (Figure 1) is neither well modeled. This last measuring point (zero uplift) and the GPS data have a certain degree of incompatibility, since GPS vectors require slip to extend at depth past below Boumerdes towards the west, resulting in a more gradual decrease of coastal uplift. Our model represents a compromise between these different tendencies.

[15] The May 21, 2003 Boumerdes-Zemmouri earthquake involved two slip zones for a total length of $55 \mathrm{~km}$ and moment magnitude $\mathrm{Mw}=6.9$. Slip occurred in almost pure reverse faulting. Maximum slip of ca $3 \mathrm{~m}$ occurred in the SW slip zone, which did not reach the surface but was confined to the depth range 11 to $2 \mathrm{~km}$. The NE slip zone was shallower and extended from $6 \mathrm{~km}$ depth to the surface. Rupture propagated bilaterally from the hypocenter and the effective duration of the rupture was $12 \mathrm{sec}$. Using various available observation of seismological waveforms and ground deformation data, we show that our approach of joint inversion leads to solution with satisfy the various observations and appear to be stable in the resolution tests. Beyond their direct use to better infer the source parameters of earthquakes, we think that this approach is important for further calculation of realistic stress changes (and their impact on triggering aftershocks and postseismic deformation), as well as tsunami generation.

[16] Acknowledgments. We are grateful to the IRIS and ORFEUS data centers for the access to broadband waveforms. Signal processing was performed using the SAC (Seismic Analysis Code) package by Peter Goldstein. Figures were partly made using the GMT (Generic Mapping Tool) package by Paul Wessel and Walter H.F. Smith. A special thank to Julien Vergoz who contributed to the seismological analysis. This manuscript was improved thanks to the contribution of two anonymous reviewers. This is contribution number 686 of Géosciences Azur.

\section{References}

Amoruso, A., L. Crescentini, and R. Scarpa (2002), Source parameters of the 1908 Messina Straits, Italy, earthquake from geodetic and seismic data, J. Geophys. Res., 107(B4), 2080, doi:10.1029/2001JB000434.

Ayadi, A., et al. (2003), Strong Algerian earthquake strikes near capital city, Eos Trans. $A G U, 84(50), 561,568$

Bounif, A., et al. (2004), The 21 May 2003 Zemmouri (Algeria) earthquake Mw 6.8: Relocation and aftershock sequence analysis, Geophys. Res. Lett., doi:10.1029/2004GL020586, in press.

Delouis, B., D. Giardini, P. Lundgren, and J. Salichon (2002), Joint inversion of InSAR, GPS, teleseismic and strong motion data for the spatial and temporal distribution of earthquake slip: Application to the 1999 Izmit mainshock, Bull. Seismol. Soc. Am., 92, 278-299.

Déverchère, J., K. Yelles, and E. Calais (2003), Active deformation along the Algerian margin (MARADJA cruise): Framework of the May 21, 003, MW $=6.8$ Boumerdes earthquake, Eos Trans. $A G U$, 84(46), Fall Meet. Suppl., Abstract S42E-0216.

Meghraoui, M. (1991), Blind reverse faulting system associated with the Mont Chenoua-Tipaza earthquake of 29 October 1989 (north-central Algeria), Terra Nova, 3, 84-93.

Nabelek, J. (1984), Determination of earthquake fault parameters from inversion of body waves, Ph.D. thesis, 361 pp., Mass. Inst. of Technol., Cambridge, Mass.

Savage, J. C. (1980), Dislocations in seismology, in Dislocations in Solids, edited by F. R. N. Navarro, pp. 252-339, North-Holland, New York.

Vallée, M. (2004), Stabilizing the empirical Green function analysis: Development of the projected Landweber method, Bull. Seismol. Soc. Am., 94, $394-409$.

Vallée, M., B. Delouis, A. Deschamps, J. Déverchère, K. Yelles, Y. Hello, and E. Calais (2003), Rupture process of the $\mathrm{Mw}=6.9$ Boumerdes (Algeria) earthquake of May 21, 2003 from seismological data, Eos Trans. $A G U, 84(46)$, Fall Meet. Suppl., Abstract S42E-0215.

Yelles-Chaouche, A. K., H. Djellit, and M. Hamdache (2003), The Boumerdes-Algiers (Algeria) earthquake of May 21st, $2003(\mathrm{Mw}=6.8)$, CSEM/EMSC Newsl., 20, 3-5.

Yelles, K., K. Lammali, A. Mahsas, E. Calais, and P. Briole (2004), Coseismic deformation of the May 21st, 2003, $\mathrm{M}_{w}=6.8$ Boumerdes earthquake, Algeria, from GPS measurements, Geophys. Res. Lett., 31, L13610, doi:10.1029/2004GL019884.

F. Benhamouda, Institut National de Cartographie et de Télédétection (INCT), Algiers, Algeria.

P. Briole, UMR 7580, CNRS, Institut de Physique du Globe, Paris, France.

E. Calais, Department of Earth and Atmospheric Sciences, Purdue University, West Lafayette, IN, USA.

B. Delouis, UMR 6526, CNRS, Géosciences Azur, 250 rue Albert Einstein, F-06560 Valbonne, France. (delouis@geoazur.unice.fr)

K. Lammali, A. Mahsas, S. Maouche, and K. Yelles, Centre de Recherche en Astronomie, Astrophysique et Geophysique (CRAAG), Algiers, Algeria.

M. Meghraoui, UMR 7516, CNRS, Institut de Physique du Globe, Strasbourg, France.

M. Vallée, Osservatorio Vesuviano, Istituto Nazionale di Geofisica e Vulcanologia, Naples, Italy. 